\title{
Hexose Transport in Microvascular Endothelial Cells Cultured from Bovine Retina
}

\author{
A. Lorris Betz, Phillip D. Bowman and Gary W. Golditein \\ (Received 12 May 1982 and accepted 6 September 1982, New York) \\ Departments of Pediatrics and Neurology, University of Michigan Medical School, \\ Awn Arbor, MI 48109, U.S.A.
}

\begin{abstract}
The nature of glucose transport at the microvascular blood-retinal barrier was atudied using primary cultures of microvascular endothelial cells from bovine retina. Uptake of 3-0-methylD-glucose (3MG), a non-metabolizable glucose analogue, was rapid and equilibrative. 3MG uptake could be inhibited by traditional glucose transport inhibitors such as phloretin, phlorizin and cytochalasin B but not by agents that deplete intracellular ATP $(2,4$-dinitrophenol) or that abolish the sodium gradient (ouabain). Cptake of $3 \mathrm{MG}$ by the cells could be stimulated by preloading with 50 mu-glucose, a phenomenon known as counter-transport. Insulin had no effect on 3MG uptake in the cells even after prolonged insulin deprivation. These results demonstrate the existence of a facilitative-difusion type of glucose transport system in endothelial cells of the retinal microvasculature. Studies with 2 -deoxy-D-glucose demonstrated that transport was not rate limiting for metabolism and that the endothelial cells contain free sugar when exposed to an extracellular sugar concentration in the physiologic range. The presence of this free sugar within the cell is necessary for efficient transendothelial transfer of glucose from blood to retina but it could also provide the basis for capillary damage in diabetes mellitus.

Key words: glucose; 3-O-methylglucose; 2-deoxyglucose; transport; metabolism; endothelial cells; blood-retinal barrier; cytochalasin B; phloretin; phlorizin; insulin.
\end{abstract}

\section{Introduction}

The existence of a permeability barrier between the blood and retina is well documented. Both the mierovascular endothelial cells and the pigment epithelial cells contribute to the formation of the blood-retinal barrier (BRB) (Cunha-Vaz, 1976). Although the movement of most polar solutes across the BRB is markedly restricted, certain metabolites can cross with ease presumably by virtue of carrier-mediated transport systems which are present in the endothelial or pigment epithelial cell membranes (Cunha-Vaz, 1976). Unrestricted movement of glucose across the BRB is particularly important since this compound is a major metabolic substrate for the retina (Graymore, 1969).

There have been several studies on the mechanism of glucose transport across the BRB in vivo (Dollery, Henkind and Orme, 1971; Tornquist, 1979) and in isolated retinal capillaries (Betz and Goldstein, 1980) or pigment epithelium in vitro (Zadunaisky and Degnan, 1976; Miller and Steinberg, 1976; Pascuzzo, Johnson and Pautler, 1980; Masterson and Chader, 1981). The mechanism of glucose transport in purified microvascular endothelial cells, however, has not been studied previously. Glucose transport and metabolism by retinal endothelial cells is of considerable interest because there is currently no explanation for the selective damage to these cells in diabetes.

Recently, several laboratories have reported methods for maintenance and growth in tissue culture of microvascular endothelial cells from retina (Bowman, Betz, and

Please address reprint requests to A. Lorris Betz, Department of Pediatrics, R6060 Kresge II, Ann Arbor, MI 48109, U.S.A. 
Goldstein, 1982; Buzney and Massicote, 1979; Frank, Kinsey, Frank, Mikus and Randolph 1979). These cultures are substantially free of contamination by other cell types and the endothelial cells in vitro retain many of the differentiated properties of retinal microvascular cells in vivo. In this study we investigated the mechanism of glucose transport in cultured capillary endothelial colls derived from bovinc retina. A preliminary report of this work was previously presented (Betz, Bowman and Goldstein, 1982).

\section{Materials and Methods}

Primary cultures of endothelial cells from bovine retinal microvessels were established using the method previously described (Bowman et al., 1982). Briefly, bovine eyes were obtained from a local slaughterhouse and transported to the laboratory on ice. The retinae were removed, trapped on a $53 \mu \mathrm{m}$ nylon mesh and washed extensively with iced tissue culture medium (Minimal Essential Medium buffered to $\mathrm{pH} 7 \cdot 4$ with $30 \mathrm{~mm}$-HEPES). The retinae were homogenized, pelleted and then treated with $0.1 \%$ collagenase/dispase at $37^{\circ} \mathrm{C}$ for $16 \mathrm{hr}$. Clumps of microvessel endothelial cells were separated from free cells and cell debris by centrifugation on a Percoll gradient. These clumps were plated into fibronectin coated wells of a 24-well multiplate. Approximately $5 \times 10^{4}$ cells were added to each well. Endothelial cell growth was supported by medium consisting of equal parts of Nutrient Mixture F-12 and Dulbecco's Modified Eagle's Medium with 10\% plasma-derived bovine serum (Bowman et al., 1982). Penicillin $(100 \mathrm{U} / \mathrm{ml})$, streptomyein $(100 \mu \mathrm{g} / \mathrm{ml})$ and fungizone $(25 \mu \mathrm{g} / \mathrm{ml})$ were added to control microbial contamination. The cells were used after $7-10$ days in culture when the monolayers were $75-100 \%$ confluent.

Prior to measurement of hexose uptake, monolayers were washed twice and then ineubated at $37^{\circ} \mathrm{C}$ for $20-30 \mathrm{~min}$ in $2 \mathrm{ml}$ of glucose-free Earle's Balanced Salt Solution. This preincubation depleted the cells of intracellular glucose so that hexose uptake could be measured in the zero-trans condition (Eilam and Stein, 1974). Hexose uptake was initiated by aspirating the preincubation solution and rapidly adding $0.25 \mathrm{ml}$ of isotope solution. Uptake was terminated by the rapid addition of $2 \mathrm{ml}$ of an iced stopping solution consisting of $140 \mathrm{mM}-\mathrm{NaCl}$, $10 \mathrm{~mm}$-HEPES, $\mathrm{pH} 7 \cdot 4$ and $0.02 \mathrm{~mm}$ cytomalasin. $\mathrm{B}$. The stopping solution was aspirated and the monolayers were then washed three more times with the same solution. This entire stopping and washing procedure was completed within $10 \mathrm{sec}$. Intracellular radioactivity was released into $0.5 \mathrm{ml}$ of $10 \%$ trichloroacetic acid and counted by liquid scintillation spectrometry. The acid treatment also caused the cell protein to precipitate and become adherent to the plate. The protein in each well was quantitated after overnight solubilization in $0.1 \mathrm{v}-\mathrm{NaOH}$ using the Biorad protein reagent.

The rate of hexose uptake and the amount of intracellular sugar at equilibrium did vary from one day to the next (e.g. the 3-O-methyl-D-glucose uptake at 1 min varied from 7.0 to $156 \mathrm{nmol} / \mathrm{mg}$ protein). It is possible that this variation was due to differences between confluent and sub-confluent cell populations as observed in fibroblasts (Kletzien and Perdue, 1974) but this possibility was not systematically tested. On any day, however, the agreement between replicates was very good and comparisons were always made to simultaneously determined controls.

For most experiments the isotope solution contained $2 \mu \mathrm{Ci}$ of $\left[{ }^{14} \mathrm{C}\right]$-hexose $(3-0$-methylD-glucose or 2-deoxy-D-glucose) and $5 \mu \mathrm{Ci}$ of $\left[{ }^{3} \mathrm{H}\right]$-L-glucose (a non-permeable sugar which was used as an extracellular reference) in $0.25 \mathrm{ml}$ of glucose-free Earle s Balanced Salt Solution. Unlabelled hexose and transport inhibitors were added where indicated. When ouabain, 2,4-dinitrophenol and insulin were used, these compounds were also present during the $30 \mathrm{~min}$ preincubation period. In the study of 2 -deoxy-D-glucose (2DG) transport and metabolism, intracellular free $2 \mathrm{DG}$ and $2 \mathrm{DG}-\mathrm{PO}_{4}$ were released into distilled water. These compounds were then separated by column chromatography using Dowex AG-1X8 resin as described previously (Betz, Csejtey and Goldstein, 1979).

The radioisotopes that were used included [glucose $\left.{ }^{14} \mathrm{C}(\mathrm{U})\right]-3-0$-methyl-D-glucose, [1$\left.{ }^{14} \mathrm{C}\right]-2$-deoxy-D-glueose, and $\left[1{ }^{3} \mathrm{H}\right]-\mathrm{L}$-glucose and were obtained from New England Nuclear Corp. (Boston, MA).. Collagenase/dispase was from Boehringer Mannheim Biochemicals 
(Indianapolis. IN) and Percoll from Pharmacia (Piscataway, N.J). Purified bovine insulin was obtained from Collaborative Research (Waltham, MA) and phloretin was purchased from $\mathrm{K}$ and K Laboratories (Plainview, NY). All lissue culture media were from GIBCO (Grand Island, NY) and other chemicals were from Sigma Chemical Company (St. Louis, MO). Protein assay kits using gammaglobulin as the standard were obtained from Biorad (Richmond, CA). Bovine fibronectin and bovine plasma-derived serum were prepared as described previously (Bowman et al., 1982).

\section{Results}

A phase contrast photomicrograph of the cultured endothelial cells from bovine retina is shown in Fig. 1. We have previously demonstrated (Bowman et al., 1982) that primary cultures of these cells retain specific endothelial cell properties such as the presence of the Factor VIII antigen and angiotensin converting enzyme and the production of a non-thrombogenic surface. In addition, they produce intercellular tight junctions similar to those seen between retinal capillary endothelial cells in vivo. 3-O-methyl-D-glucose (3MG) was used as a model substrate for characterization of the D-glucose transport system. This sugar is non-metabolizable (Czaky and Wilson, 1956) and has becn used to study hexose transport by isolated retinal capillaries (Betz and Goldstein, 1980). Figure 2 shows the time course for the uptake of 5 mi-3MG and its inhibition by $0.02 \mathrm{~mm}$-cytochalasin B. The non-transported sugar, L-glucose, was used to measure the rate of simple diffusion and also to correct for extracellular radioactivity that was not removed by the washing procedure. Since $\left[{ }^{3} \mathrm{H}\right]-\mathrm{L}-$ glucose was present in all of the ineubations with $\left[{ }^{14} \mathrm{C}\right]-3 \mathrm{MG}$, the background could be determined and the $3 \mathrm{MG}$ uptake corrected for each sample. This L-glucose correction has been applied to all values for $3 \mathrm{MG}$ uptake in this report. From the data in Fig. 2 it is apparent that $3 \mathrm{MG}$

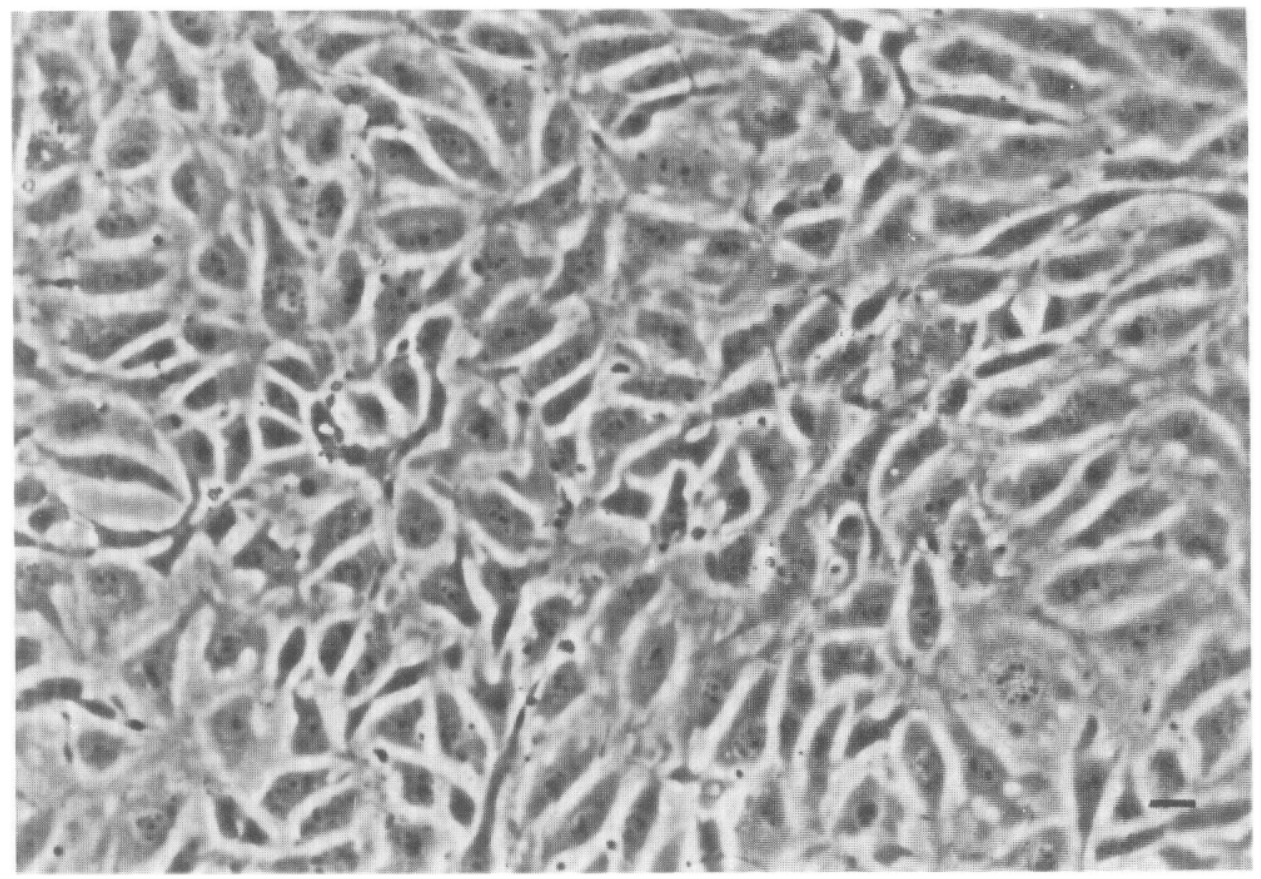

FIG. 1. Phase cuntrast photomicrograph of cultured endothelial cells from bovine retina. Bar $=10 \mu \mathrm{m}$ 


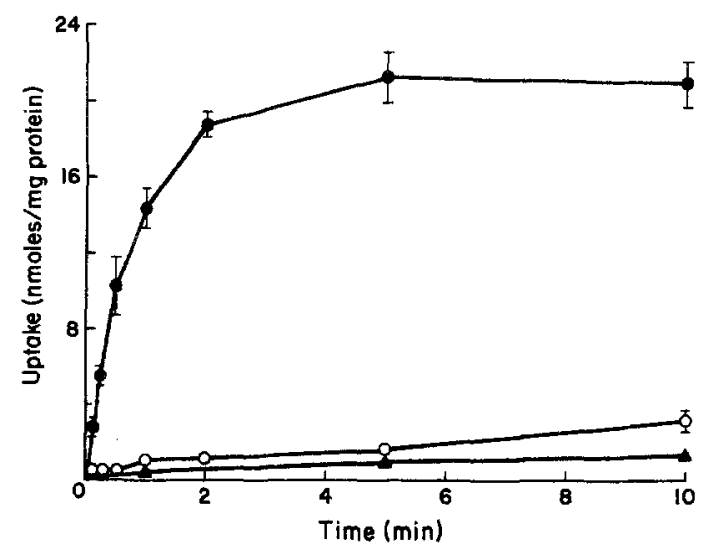

Fig. 2. Uptake at $22^{\circ} \mathrm{C}$ of $5 \mathrm{mM}-\left[{ }^{14} \mathrm{C}\right]-3 \mathrm{MG}(\mathrm{O}), 5 \mathrm{mM}-\left[{ }^{14} \mathrm{C}\right]-3 \mathrm{MG}$ in presence of $0.02 \mathrm{~mm}-\mathrm{cytochalasin} \mathrm{B}$ (O), or $5 \mathrm{mM}-\left[{ }^{3} \mathrm{H}\right]-\mathrm{L}-\mathrm{glucose}(\mathbf{A})$. Data shown are the averages of three determinations \pm s.D. When S.D. is not indicated it was less than $10 \%$ of the average uptake.

TABLE I

Effect of potential sugar transport inhibitors

\begin{tabular}{|c|c|c|}
\hline Compound & $\begin{array}{c}\text { Concentration } \\
(\mathrm{mM})\end{array}$ & $\begin{array}{c}\text { Uptake } \\
(\mathrm{nmol} / \mathrm{mg} / \mathrm{min})\end{array}$ \\
\hline \multicolumn{3}{|l|}{ Group I } \\
\hline Control & - & $9 \cdot 8 \pm 2 \cdot 6$ \\
\hline Cytochalasin B & $0 \cdot 01$ & $0-2 \pm 0.1 *$ \\
\hline Phloretin & $0 \cdot 10$ & $2 \cdot 7 \pm 0.5 *$ \\
\hline Phlorizin & 0.50 & $6 \cdot 9 \pm 1 \cdot 3 \dagger$ \\
\hline \multicolumn{3}{|l|}{ Group II } \\
\hline Control & 一 & $8 \cdot 5 \pm 0 \cdot 9$ \\
\hline 2,4-Dinitrophenol & $0 \cdot 10$ & $8 \cdot 2 \pm 0.5$ \\
\hline Ouabain & $0 \cdot 10$ & $7 \cdot 4 \pm 0 \cdot 6 \div$ \\
\hline
\end{tabular}

Uptake of $\left[{ }^{14} \mathrm{C}\right]-3 \mathrm{MG}(5 \mathrm{mM})$ was determined during a 1 min incubation at $22^{\circ} \mathrm{C}$ in the presence of inhibitor. In Group I the inhibitor was added at zero time, while in Group II, the inhibitor was also present during the $30 \mathrm{~min}$ preincubation at $37^{\circ} \mathrm{C}$ in glucose-free Earle's Balanced Salt Solution. The data are expressed per $\mathrm{mg}$ of cell protein and have been corrected for extracellular $3 \mathrm{MG}$ using $\left[{ }^{3} \mathrm{H}\right]-\mathrm{L}$-glucose, Values are averages of three determinations \pm S.D. Student's $t$ test was used to identify values significantly less than control.

* $P<0.001,+P<0.05$

$\ddagger$ n.s.

uptake occurs very rapidly even at $22^{\circ} \mathrm{C}$. Hexose uptake is almost completely eliminated by cytochalasin B, a known inhibitor of hexose transport in several other cell types including isolated retinal capillaries (Betz and Goldstein, 1980). The data in Table I show that phloretin and phlorizin are effective inhibitors of sugar transport into retinal endothelial cells; however, phloretin is more potent than phlorizin. This relative potency was observed in isolated retinal capillaries (Betz and Goldstein, 1980) and is characteristic of a facilitative-diffusion type of glucose transport system. Further evidence for this transport mechanism is provided by the fact that there is no significant change in $3 \mathrm{MG}$ uptake if the cells are preincubated with either an inhibitor of energy metabolism (2,4-dinitrophenol) or with an inhibitor of active 


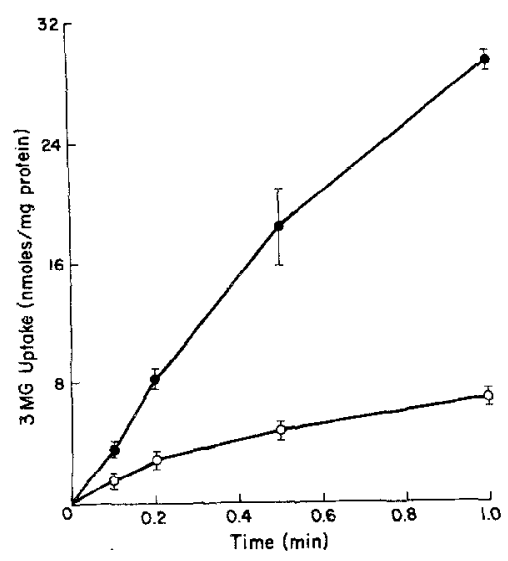

Fic. 3.

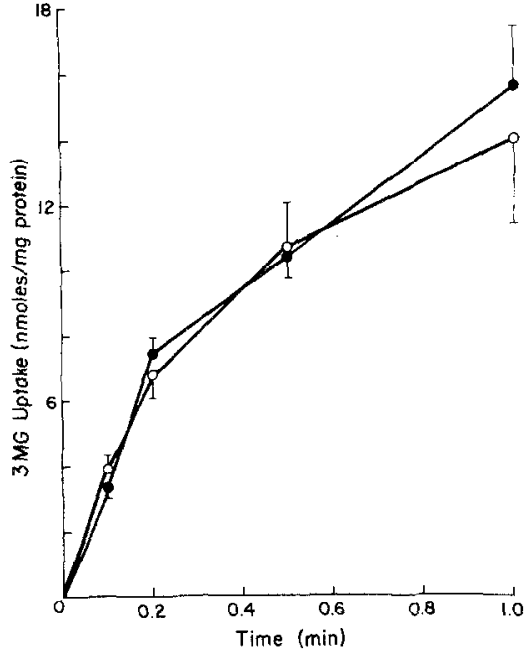

FIG. 4.

Fra. 3. Stimulation of 3MG uptake by counter-transport. Cultured endothelial cells were preincubated for 30 min in Earle's Balunced Salt Solution (EBS) that was giveose free $(O)$ or which contained $50 \mathrm{mM}-\mathrm{D}$-glucose (O). The cells were then quickly washed with glucose-free EBS and the uptake of 5 mM- $\left[{ }^{14} \mathrm{C}\right]-3 \mathrm{MG}$ was measured at $22^{\circ} \mathrm{C}$. $\left[{ }^{3} \mathrm{H}\right]$-L-glucose was used to correct for extracellular $3 \mathrm{MG}$. Data shown are the averages of three determinations \pm s.D.

FiG. 4. Hexose uptake in insulin depleted cultures. Monolayers of endothelial cells were maintained in serum-free, insulin-free medium for $18 \mathrm{hr}$. They were then incubated for $20 \mathrm{~min}$ at $37^{\circ} \mathrm{C}$ in glucose-free Earle's Balanced Salt Solution containing $0.1 \%$ recrystallized bovine serum albumin without $(O)$ or with (O) $10 \mu \mathrm{g} / \mathrm{ml}$ of bovine insulin. Uptake of $5 \mathrm{~mm}-\left[{ }^{14} \mathrm{C}\right]-3 \mathrm{MG}$ was measured at $22^{\circ} \mathrm{C}$ and corrected for extracellular 3MG using [ $\left.{ }^{3} \mathrm{H}\right]-\mathrm{L}-$ glucose. Data shown are the averages of three determinations \pm s.D.

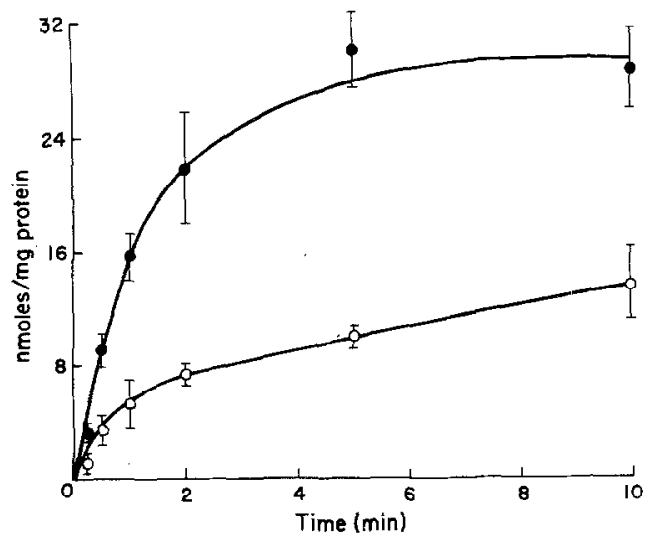

FIG. 5. Comparison of hexose transport and phosphorylation. Cultured endothelial cells were preincubated for $20 \mathrm{~min}$ in glucose-free Earle's Balanced Salt Solution and then for various periods of time at $37^{\circ} \mathrm{C}$ in the same solution now containing $5 \mathrm{~mm}-\left[{ }^{14} \mathrm{C}\right]-2 D G$. Intracellular radioactivity was released into water and fractionated between free $2 \mathrm{DG}(\mathrm{O})$ and $2 \mathrm{DG}-\mathrm{PO}_{4}(\mathrm{O})$. The free 2DG content was corrected for extracellular $2 \mathrm{DG}$ using $\left[{ }^{3} \mathrm{H}\right]$-L-glucose. Data shown are the averages of 3 determinations \pm S.D. 
sodium transport (ouabain). Therefore, sugar transport into retinal endothelial cells is not dependent on energy or the sodium gradient. Stimulation of cellular uptake by a high concentration of another solute within the cell is known as counter-transport (Wilbrandt, 1975). This phenomena occurs in facilitative-diffusion types of transport systems and has been used as evidence for the presence of a mobile carrier. Figure 3 shows that $3 \mathrm{MG}$ uptake into cultured retinal endothelial cells is increased if the cells are pre-equilibrated with $50 \mathrm{mM}$-D-glucose.

In our previous study we demonstrated that exogenous insulin did not stimulate hexose uptake into isolated retinal capillaries (Betz and Goldstein, 1980). However, we could not eliminate the possibility that sugar uptake was already maximally stimulated by endogenous insulin which might have been retained during the isolation procedure. In the present study, we were able to maintain the cultured endothelial eclls for more than $18 \mathrm{hr}$ in serum free medium containing no insulin. When insulin was added back to the insulin-depleted cultures, there was no effect on $3 \mathrm{MG}$ uptake (Fig. 4). Thus, there is no evidence that glucose transport into the microvascular endothelial cells of the retina is affected by insulin.

The relationship between glucose transport and its subsequent metabolism was studied using 2-deoxy-D-glucose (2DG) since this sugar is transported by the hexose transport system and then phosphorylated irreversibly by hexokinase but it is not further metabolized (Sols and Crane, 1954). It is clear from the data shown in Fig. 5 that transport of $2 \mathrm{DG}$ into the cells occurs more rapidly than phosphorylation. This relationship was also found in isolated retinal capillaries (Betz and Goldstein, 1980 ) but it is in contrast to studies in cells such as cultured fibroblasts where transport is rate limiting for metabolism (Kletzien and Perdue, 1975).

\section{Discussion}

The term 'blood-retinal barrier' has been used to describe the limited retinal uptake of certain solutes. It is obvious, however, that in addition to being an impermeable wall, the BRB must also be selectively permeable to solutes that are important for retinal metabolism. In fact, in vivo studies have shown that the BRB is a highly selective 'sieve' allowing D-glucose but not L-glucose to enter the retina from the blood (Dollery et al., 1971). This selectivity is presumably due to the presence of specific transport systems in the BRB. Anatomically, both the capillary endothelial cells and pigment epithelial cells contribute to the BRB (Cunha-Vaz, 1976). The relative role of each structure in allowing glucose to enter the retina has been studied in vivo (Tornquist and Alm, 1979) but the method used does not allow investigation of the transport mechanisms at a cellular level. Therefore, several investigators have used isolated preparations for such studies.

Using the isolated pigment epithelium from amphibians, Zadunaisky and Degnan (1976) demonstrated net movement of 3MG from choroidal to apical surface. With the same preparation, however, Miller and Steinberg (1976) were unable to detect any net flux of $3 \mathrm{MG}$. Recently, Pascuzzo, Johnson and Pautler (1980) concluded that there is a sodium-dependent glucose transport system in the isolated sheep pigment epithelium. Glucose transport has also been studied in cultured chick pigment epithelium where it was found to be stereospecific and not energy-dependent (Masterson and Chader, 1981). Hexose transport in this system appeared to occur by a facilitative-diffusion type of system. It is not clear whether the poor agreement between the conclusions of these various studies is due to methodologic or species differences. 
We previously studied hexose transport into microvessels isolated from bovine retina (Betz and Goldstein, 1980). Although isolated capillary preparations have at least two cell types present (endothelial and pericyte) our findings were identical to the results of our present study using cultured retinal endothelium. It therefore appears very likely that the capillary endothelium in the retina contains a facilitative-diffusion type of hexose transport system that is not energy-or sodium-dependent and which is not affected by insulin. This transport system permits glucose to enter the endothelial cells more rapidly than it can be metabolized by these cells and when the glucose concentration is in the physiologic range there is always free glucose within the endothelial cell. This relationship between hexose transport and metabolism by endothelial cells allows for efficient transendothelial movement of $\mathrm{D}$-glucose from blood to retina. An analogous hexose transport system has been described at the blood-brain barrier in vivo (Lund-Anderson, 1979), in isolated brain capillaries in vitro (Betz et al., 1979) and in cultured endothelial cells from human umbilical vein (Corkey, Corkey and Gimbrone, 1981).

It must be acknowledged, however, that our conclusions on the relationship between glucose metabolism within the endothelial cell and transendothelial glucose transport are based on studies mcasuring transport into but not across a monolayer of endothelial cells. It is likely that transport into the cell is the first step in transendothelial transport, however, this proposition is unproven. Future studies on hexose transport across monolayers of endothelial cells grown on a permeable support should clarify this relationship.

Besides providing information on the mechanisms of $D$-glucose transport from blood to retina, studies of hexose transport in retinal endothelial cells are also of interest because of the damage that occurs to these vessels in diabetes mellitus. Although most capillary endothelial cells are affected to some extent by diabetes, the capillary endothelial cells of the retina appear to be the most severely damaged (Cunha-Vaz, 1978). Experimental studies suggest that there is an early breakdown in the microvascular BRB even before gross morphologic changes have occurred (CunhaVaz, Faria de Abreu, Campos and Figo, 1975). In later stages, the typical pattern of diabetic retinopathy is seen which consists of endothelial cell degeneration and proliferation with formation of microaneurysms (Cunha-Vaz, 1978). The mechanism of damage to the endothelial cells in diabetes is unknown.

It is probable that the high incidence of cataract formation in diabetics is due to the accumulation of sorbitol within the lens which causes osmotic damage (Gabbay, 1973). Under normal conditions, little sorbitol can be formed from glucose because aldose reductase, the enzyme responsible for this conversion, has a high $\mathbf{K}_{m}$ for glucose. However, when the ambient glucose concentration is increased, as in diabetes, the intracellular glucose concentration in the lens increases and sorbitol is formed. This can occur because the rate of glucose transport into the lens cell is faster than its metabolism and there is always a pool of free ghocose in equilibrium with extracellular glucose. Our study demonstrates that a similar relationship between transport and metabolism is present in retinal capillary endothelial cells. If the endothelial cells also contain aldose reductase, they might then synthesize sorbitol when the blood glucose is high. One study failed to detect immunoreactive aldose reductase in isolated capillaries, which contain endothelial cells and pericytes, but did find the enzyme in cultured pericytes (Buzney, Frank, Varma, Tanishima and Gabbay, 1977). Furthermore, cultured retinal pericytes (Buzney et al., 1977) and endothelial cells from human umbilical veins (Corkey, Corkcy and Gimbrone, 1978) produce sorbitol in direct proportion to the ambient glucose concentration. Therefore, the ability of 
microvascular endothelium from retina to synthesize sorbitol warrants further investigation. We believe that primary cultures of retinal endothelial cells will provide a useful system for these investigations since the cells appear to retain many of their differentiated properties.

\section{ACKNOWLEDGMENTS}

The authors thank Janet Mullen, Diune Ar and Otho Artis, Jr. for their valuable technical assistance. This work was supported by Grants EY 03772, ES 02380, and HL 26480 from the National Institutes of Health. A. L. Betz is an Established Investigator of the American Heart Association.

\section{REFERENCES}

Betz, A. L., Bowman, P. D. and Goldstein, G. W. (1982) Hexose transport in endothelial cells cultured from retinal microvessels. Microvasc. Res. 23, 242.

Betz, A. L., Csejtey, J. and Goldstein, G. W. (1979). Hexose transport and phosphorylation by capillaries isolated from rat brain. Am. J. Physiol. 236, $096-\mathrm{C} 102$.

Betz, A. L. and Goldstein, G. W. (1980). Transport of hexoses, potassium and neutral aminn acids into capillaries isolated from bovine retina. Exp. Eye Res. 30, 593-605.

Bowman, P. D., Betz, A. L. and Goldstein, G. W. (1982). Primary culture of microvascular endothelial cells from bovine retina: Selective growth using fibronectin-coated substrate and plasma-derived serum. In vitro. 18, 626-32.

Buzney, S. M. and Massicote, S. J. (1979). Retinal vessels: Proliferation of endothelium in vitro. Invest. Ophthalmol. 18, 1191-5.

Buzney, S. M., Frank, R. N., Varma, S. D., Tanishima, T. and Gabbay, K. H. (1977). Aldose reductase in retinal mural cells. Invest. Ophthalmol. 16, 392-6.

Corkey, R. F., Corkey, B. E. and Gimbrone, M. A. (1978). Hexose transport and sorbitol accumulation in cultured human endothelial cells. Diabetes 27, 446.

Corkey, R. F., Corkey, B. E. and Gimbrone, M. A. (1981). Hexose transport in normal and SV40-transformed human endothelial cells in culture. $J$. Cell. Physiol. 106, 425-34.

Cunha-Vaz, J. G. (1978). Pathophysiology of diabetic retinopathy. Br. J. Ophthalmol. 62, $351-5$.

Cunha-Vaz, J. G. (1976). The blood-retinal barriers. Doc. Ophthalmol. 41, 287-327.

Cunha-Vaz, J. G., Faria de Abreu, J. R., Campos, A. J. and Figo, G. M. (1975). Early breakdown of the blood-retinal barrier in diabetes. Br. J. Ophthatmol. 59, 649-56.

Czaky, T. Z. and Wilson, J. E. (1956). The fate of $3-{ }^{-14} \mathrm{CH}_{3}$-glucose in the rat. Biochim. Biophys. Acta 22, 185-6.

Dollery, C. T., Henkind, P. and Orme, M. L'E. (1971). Assimilation of D and L 1-C-14 glucose into the retina, brain and other tissues. Diabetes 20, 519-21.

Eilarn, Y. and Stein, W. D. (1974). Kinetic studies of transport across red blood cell membranes. In Methods in Membrane Biology (Ed. Korn, E. D.). Vol. 1. Pp. 283-354. Plenum Press, New York.

Frank, R. N., Kinsey, V. E., Frank, K. W., Mikus, K. P. and Randolph, A. (1979). In vitro proliferation of endothelial cells from kitten retinal capillaries. Invest. Ophthalmol. 18, $1195-1200$.

Gabbay, K. H. (1973). The sorbitol pathway and the complications of diabetes. N. Engl. J. Med. 288, 831-6.

Graymore, C. N. (1969). General aspects of the metabolism of the retina. In The Eye, Vol. 1, (Ed. Davson, H.). Pp. 601-45. Academic Press, New York.

Kletzien, R. F. and Perdue, J. F. (1974). Sugar transport in chick embryo fibroblasts. I. A functional change in the plasma membrane associated with the rate of cell growth. $J$. Biol. Chem. 249, 3366-74.

Kletzien, R. F. and Perdue, J. F. (1975). Induction of sugar transport in chick embryo fibroblasts by hexose starvation. Evidence for transeriptional regulation of transport. J. Biol Chem. 250, 593-600. 
Lund-Anderson, H. (1979). Transport of glucose from blood to brain. Physiol. Rev. 59, 305-52. Masterson, E. and Chader, J. (1981). Characterization of glucose transport by cultured chick pigmented epithelium. Exp. Eye Res. 32, 279-89.

Miller, S. and Steinberg, R. H. (1976). Transport of taurine, L-methionine and 3-0-methylD-glucose across frog retinal pigment epithelium. Exp. Eye Res. 23, 177-89.

Pascuzzo, G. J., Johnson, J. E. and Pautler, E. L. (1980). Glucose transport in isolated mammalian pigment epithelium. Exp. Eye Res. 30, 53-8.

Sols, A. and Crane, R. K. (1954). Substrate specificity of brain hexokinase. J. Biol. Chem. $210,581-95$.

Tornquist, P. (1979). Capillary permeability in cat choroid, studied with the single injection technique (II). Acta Physiol. Scand. 106, 425-30.

Turnquist, P. and Alm, A. (1979). Retinal and choroidal contribution to retinal metabolism in vivo. A study in pigs. Acta Physiol. Scand. 106, 351-7.

Wilbrandt, W. (1975). Criteria in carrier transport. In Methods in Membrane Biology Vol. 7. (Ed. Eisenberg, II., Katchalski-Katzir, E. and Manson, L. A.). Pp. 11-31. Plenum Press, New York.

Zadunaisky, J. A. and Degnan, K. J. (1976). Passage of sugars and urea across the isolated retina pigment epithelium of the frog. Exp. Eye Res. 23, 191-6. 